R O Z D Z I A \pm 4 .

\title{
SPÓŁDZIELCZY SPOSÓB GOSPODAROWANIA W XXI WIEKU
}

\author{
Krystyna Zimnoch ${ }^{1}$
}

\section{Wstęp}

Dzisiaj rzadko używa się pojęcia gospodarowanie. Powszechnie stosuje się pojęcia model biznesowy i biznes. Warto przypomnieć co oznacza gospodarowanie: ludzkie działanie zmierzające do zaspokojenia potrzeb. Na pewnym etapie rozwoju działanie to stało się procesem produkcji i konsumpcji. W procesie produkcji następuje wykorzystanie zasobów i przekształcanie ich w produkty (i usługi) zaspokajające potrzeby człowieka, oddawane konsumpcji. Zaspokojenie naszych potrzeb zależy więc od tego, co w procesie produkcji powstaje. Współcześnie jako konsumenci i właściciele czynników produkcji często mamy na to niewielki wpływ. Zdani jesteśmy na panujący powszechnie kapitalistyczny sposób produkcji i konsumpcji. Buntując się niejako szukamy rozwiązań pozwalających nam na wolność wyboru tego, co chcemy jeść, robić i jak żyć. Współczesne kooperatywy spożywcze, które łączą osoby dążące do zdrowego stylu życia poprzez tworzenie możliwości nabycia zdrowej żywności, w swoich dążeniach niczym nie różnią się od Sprawiedliwych Pionierów z Rochdale. Ci pionierzy spółdzielczości założyli w 1844 roku własne przedsiębiorstwo spółdzielnię. Ówcześni angielscy tkacze chcieli kupować podstawowe

\footnotetext{
${ }^{1}$ Dr Krystyna Zimnoch, Politechnika Białostocka.
} 
artykuły żywnościowe dobrej jakości, za godziwą cenę, nie chcieli być oszukiwani na wadze i nie chcieli podłego towaru. Zakładali swoje sklepy i sami wybierali dostawców. W odpowiedzi na lichwiarski procent ludzie tworzyli kasy pożyczkowe. Po I i II wojnie światowej inwalidzi, chcąc żyć godziwie także tworzyli swoje spółdzielnie. Zawsze więc potrzeby ludzi-członków i ich wartości wyznaczały cele działania spółdzielni i sposób ich realizacji.

Od początku ruchu spółdzielcy stawiali sobie cele realne: proste działania dla zaspokojenia potrzeb. Polskie spółdzielnie poszczególnych branż powstały jeszcze w okresie zaborów przed odzyskaniem niepodległości przez państwo polskie w 1918 roku. Dlatego historycznie ich misja widziana była przez członków założycieli jako zachowanie polskiej narodowej własności zasobów: ziemi, kapitału, pracy i nauki. „Zakładanie spółdzielni to budowanie twierdz polskości”. W okresie pierwszej gospodarki rynkowej w Polsce - dwudziestolecia międzywojennego - autorzy polityki gospodarczej rozumieli siłę przedsiębiorstw spółdzielczych w tworzeniu kapitału odradzającej się polskiej gospodarki. Potwierdzała to ustawa o spółdzielniach z 1920 roku i zaangażowanie różnych grup społecznych, również przez wychowanie w spółdzielniach uczniowskich. W ruch spółdzielczy angażowała się elita naukowa i kulturalna. Do propagatorów spółdzielczości należeli: Zofia Daszyńska-Golińska, Ludwik Krzywicki, Maria Dąbrowska, Stefan Żeromski, wykładowcy Uniwersytetu Warszawskiego, Uniwersytetu Jagiellońskiego, Wyższej Szkoły Handlowej, Szkoły Głównej Gospodarstwa Wiejskiego, politycy: Jędrzej Moraczewski, Stanisław Wojciechowski, Zygmunt Chmielewski, Franciszek Stefczyk, Józef Beck, a także duchowni ks. Stanisław Adamski².

Żeby wyjaśnić możliwości spółdzielni jako źródła akumulacji kapitału trzeba przypomnieć zasady spółdzielcze nieodłącznie związane z pojęciem

${ }^{2}$ R R. Okraska, Od samopomocy do wizji nowego ustroju. Zarys dziejów rozwoju materialnego i ideowego spótdzielczości w Polsce do roku 1939, [w:] Kooperatyzm, spółdzielczość, demokracja. Wybór pism, Wydawnictwo Uniwersytetu Warszawskiego, Warszawa 2014, s. 60. 
spółdzielni. „Spółdzielnia jest autonomicznym zrzeszeniem osób, które zjednoczyły się dobrowolnie w celu zaspokojenia swoich wspólnych aspiracji i potrzeb ekonomicznych, społecznych i kulturalnych poprzez współposiadane i demokratycznie kontrolowane przedsiębiorstwo"3. Taką definicję spółdzielni podaje Międzynarodowy Związek Spółdzielców (MZS). Spółdzielczość posiada charakter bimodalny, ponieważ jest zrzeszeniem osób oraz przedsiębiorstwem. Zrzeszenie osób jest podstawowym elementem spółdzielni, a z punktu widzenia socjologicznego jest z nią tożsame. Każda grupa społeczna, a zwłaszcza grupa o charakterze zrzeszeniowym, ma oprócz wspólnego celu, metod działania i mniej lub bardziej wyraźnych struktur władzy, pewien zasób środków materialnych, stanowiących jej wyposażenie. W przypadku spółdzielni środkami tymi są przede wszystkim udziały członkowskie oraz założone za ich pomocą wspólne przedsiębiorstwo spółdzielcze służące do realizacji celów grupowych $^{4}$.

W spółdzielni łączy ludzi wspólne działanie, które determinują wartości spółdzielców. Wybierają jako formę działalności spółdzielnię z przekonaniem o możliwości ich zachowania i działania zgodnie z nimi. Gwarantują to zasady spółdzielcze. Wypracowali je wspomniani Pionierzy z Rochdale. Zasady te zostały przyjęte przez ruch spółdzielczy na całym świecie. Modyfikowane przez Międzynarodowy Związek Spółdzielczy w XX wieku trzykrotnie (rok 1937, 1966, 1995) w odpowiedzi na zachodzące $\mathrm{w}$ świecie zmiany strukturalne i społeczne, przyjmują dziś następujące brzmienie ${ }^{5}$ :

1) zasada dobrowolnego i otwartego członkostwa;

2) zasada demokratycznej kontroli członkowskiej;

3) zasada ekonomicznego uczestnictwa członków;

${ }^{3}$ International Co-operative Alliance http://ica.coop/en/whats-co-op/co-operative-identity-values-principles [data dostępu: 30.06.2019].

${ }^{4}$ W. Czternasty, Determinanty rozwoju spółdzielczości $w$ różnych warunkach ekonomiczno-społecznych, Wydawnictwo Adam Marszałek, Toruń 2013, s. 197-199.

${ }^{5}$ International Co-operative Alliance, dz. cyt. 
4) zasada autonomii i niezależności;

5) zasada kształcenia; szkolenia i informacji;

6) zasada współpracy międzyspółdzielczej;

7) zasada troski o lokalną społeczność.

Gwarancja spółdzielczego demokratyzmu, autonomii i niezależności przekonuje do ekonomicznego uczestnictwa, a więc do włączenia swoich prywatnych zasobów. Nie polega to jednak na inwestowaniu kapitału z myślą o maksymalizacji zysku, które cechuje przedsiębiorstwa kapitalistyczne. Spółdzielcy chcą zaspokoić swoje potrzeby, maksymalizują użyteczność. Kryterium oceny efektów ich działania jest więc poczucie zaspokojenia potrzeb, satysfakcja z ich realizacji, przydatność i skuteczność działań.

Spółdzielczy model biznesowy oparty na współpracy od prawie dwóch stuleci odgrywa ważną rolę w rozwoju gospodarczym, tworzeniu miejsc pracy i rozwiązywaniu problemów rynkowych ${ }^{6}$. Współcześnie idea rozwoju zrównoważonego i koncepcja społecznej odpowiedzialności biznesu skłania do spojrzenia na przedsiębiorstwa przez pryzmat aspektów społecznych, a nie wyłącznie ekonomicznych. W nielicznych jeszcze publikacjach próbuje się opisywać przedsiębiorstwa społeczne i gospodarkę społeczną. Niemniej jednak przedsiębiorczość społeczna jako przedmiot badań jest dopiero wschodzącą dziedziną ${ }^{7}$. A definicje i koncepcje przedsiębiorstwa społecznego mogą być zróżnicowane w poszczególnych kontekstach społecznych, gospodarczych i politycznych ${ }^{8}$. Podkreślić jednak trzeba, że prekursorem społeczności w gospodarowaniu były przedsiębiorstwa spółdzielcze. Spółdzielnie powstały jako alternatywa dla kapitalistycznego sposobu

${ }^{6}$ T. Mazzarol, D. Clark, S. Reboud, E.M. Limnios, Developing a conceptual framework for the co-operative and mutual enterprise business model, "Journal of Management \& Organization" 2018, t. 24, nr 4, s. 551-581.

${ }^{7}$ M. Dionisio, The evolution of social entrepreneurship research: a bibliometric analysis, "Social Enterprise Journal" 2019, t. 15, nr 1, s. 22-45.

${ }^{8}$ E. Bidet, H. Eum, J. Ryu, Diversity of Social Enterprise Models in South Korea, "Voluntas" 2018, t. 29, nr 6, s. 1261-1273. 
produkcji i konsumpcji. I wciąż taką alternatywą pozostają w dążeniu do dobrostanu ludzi i środowiska.

Spółdzielczy sposób gospodarowania wydaje się więc aktualnym i ważnym obszarem badawczym. Celem rozważań w niniejszym rozdziale pozostaje wobec tego zdiagnozowanie stanu przedsiębiorczości spółdzielczej na świecie i w Polsce, z uwzględnieniem rolnictwa i obszarów wiejskich. Wykorzystano do tego analizę raportów Międzynarodowego Związku Spółdzielczego (MZS), Europejskiego Instytutu Badań Spółdzielczości i Przedsiębiorstw Społecznych (EURICSE) oraz raportów krajowych organizacji spółdzielczych i danych statystyki publicznej.

\subsection{Kondycja przedsiębiorstw spółdzielczych}

Upowszechniając idee spółdzielczości i przedsiębiorczości społecznej Międzynarodowy Związek Spółdzielczy, wspólnie z Europejskim Instytutem Badań Spółdzielczości i Przedsiębiorstw Społecznych, od 2006 roku publikuje Raport Global 300. Prezentowane w nim są największe spółdzielnie i przedsiębiorstwa społeczne na świecie. Raport ukazuje się w specjalnym wydaniu World Co-operative Monitor (WCM). Global 300 obejmuje przedsiębiorstwa społeczne z kilkudziesięciu krajów świata o rocznym obrocie powyżej 100 milionów dolarów. Jest to jedyny tego rodzaju raport zbierający roczne dane ekonomiczno-finansowe dotyczące globalnego ruchu spółdzielczego i przedsiębiorczości społecznej ${ }^{9}$.

W najnowszym World Co-operative Monitor z roku 2017 przedstawiono sprawozdanie ukazujące największe na świecie przedsiębiorstwa społeczne, z wykorzystaniem danych finansowych z 2015 roku. W WCM zebrano dane dotyczące 2379 przedsiębiorstw z ośmiu sektorów (1449 z Europy, 702 z obu Ameryk, 216 z Azji, 12 z Afryki). Aż 1436 organizacji

${ }^{9}$ I. Bretos, M. Diaz-Foncea, C. Marcuell, Cooperatives and internationalization: An analysis of the 300 largest cooperatives in the world, "Ciriec-Espana Revista de Economia Publica Social y Cooperativa” 2018, nr 92, s. 5-37. 
miało obrót powyżej 100 mln USD, tworząc TOP 300. Największy udział wśród zgłoszonych organizacji mają przedsiębiorstwa z następujących branż: rolnictwo i przemysł spożywczy - 23\%, ubezpieczenia - 18\%, bankowość - 12\%, handel hurtowy i detaliczny - 8\%. Natomiast udział przedsiębiorstw z branży przemysłowej wynosi 5\%, podobnie jak spółdzielni działających w branży zdrowie, edukacja i opieka społeczna. 1\% przedsiębiorstw spółdzielczych przedstawionych w raporcie działa w innych obszarach $^{10}$.

Na najnowszej liście Global 300 znalazły się spółdzielnie z 27 krajów, ich łączny obrót w roku 2015 wyniósł 2164.23 biliona USD. Największy udział w tej wartości ma branża ubezpieczeniowa - 41\%, rolnictwo i przemysł spożywczy - 30\%, handel hurtowy i detaliczny - 19\%, bankowość - 6\%.

W pierwszej dziesiątce największych spółdzielni na świecie znalazły się cztery spółdzielnie z Francji, trzy z branży bankowości oraz jedna z branży handlowej. Drugie i trzecie miejsce przypadło spółdzielniom amerykańskim z branży ubezpieczeniowej ${ }^{11}$. Największe przedsiębiorstwa spółdzielcze z Niemiec reprezentują sektor bankowy i usług finansowych oraz handel hurtowy i detaliczny. Wśród największych spółdzielni znalazły się też dwie spółdzielnie z Japonii, obie z branży ubezpieczeniowej. Listę dziesięciu największych przedsiębiorstw społecznych wraz z ich krajem pochodzenia i branżą przedstawiono w tabeli 4.1.

Rozwój przedsiębiorstw spółdzielczych w XXI wieku charakteryzuje wyraźnie wzrostowa tendencja, ale też wewnętrzna dynamika. W literaturze często opisywana jest największa spółdzielnia na świecie - Hiszpańska Korporacja Spółdzielcza Mondragon, która może śmiało konkurować z wielkimi przemysłowymi koncernami międzynarodowymi. Mondragon

${ }^{10}$ World Co-operative Monitor, Exploring the Co-operative Economy Report 2017, s. 20-21, 80, www.euricse.eu/wp-content/uploads/2017/11/WCM_2017-web-EN.pdf [data dostępu: 30.06.2019].

11 Tamże. 
jest jedną z największych na świecie federacji spółdzielczych. Pomimo iż w latach 2011-2015 jej obrót spadł o 18,4\%, to znajduje się ona na czele 10 największych na świecie spółdzielni w branży przemysłowej oraz narzędziowej i na 35 pozycji Global $300^{12}$. Badania pokazują, że wyniki gospodarcze spółdzielni w porównaniu z konwencjonalnymi spółkami należącymi do inwestorów w Hiszpanii w latach kryzysu gospodarczego nie były gorsze ${ }^{13}$.

Tabela 4.1. Największe przedsiębiorstwa społeczne według GLOBAL 300 Report 2017

\begin{tabular}{cccc}
\hline Pozycja & Przedsiębiorstwo & Kraj & Branża \\
\hline \hline 1 & Groupe CréditAgricole & France & Bankowość i usługi finansowe \\
\hline 2 & Kaiser Permanente & USA & Ubezpieczenia \\
\hline 3 & State Farm & USA & Ubezpieczenia \\
\hline 4 & BVR & Germany & Bankowość i usługi finansowe \\
\hline 5 & Zenkyoren & Japan & Ubezpieczenia \\
\hline 6 & Groupe BPCE & France & Bankowość i usługi finansowe \\
\hline 7 & REWE Group & Germany & Handel hurtowy i detaliczny \\
\hline 9 & Groupe CréditMutuel & France & Bankowość i usługi finansowe \\
\hline 10 & Nippon Life & Japan & Ubezpieczenia \\
\hline
\end{tabular}

Źródło: opracowanie własne na podstawie World Co-operative Monitor, Exploring the Co-operative Economy Report 2017, www.euricse.eu/wp-content/uploads/2017/11/WCM_2017-web-EN. pdf [data dostępu 30.06.2018], s. 8.

${ }^{12}$ World Co-operative Monitor..., dz. cyt.

${ }^{13}$ P.A. Montero, A.R. Pacheco, Capitalist enterprises versus cooperative enterprises: comparative analysis of economic and financial results for Spain in 2008-2015, "Ciriec-Espana Revista de Economia Publica Social y Cooperative" 2018, t. 93, s. $115-154$. 
Zawarta w ostatnim raporcie analiza trendów działalności 100 największych przedsiębiorstw społecznych w latach 2011-2015 wyraźnie pokazuje wzrost. Branża rolnicza nie ustępuje dynamiką spółdzielczemu sektorowi bankowemu i ubezpieczeniowemu, w okresie 2011-2015 dynamika obrotów przedsiębiorstw tej branży wyniosła 17,63\% ${ }^{14}$. Ta sekcja obejmuje wszystkie spółdzielnie działające w całym rolniczym łańcuchu wartości, począwszy od uprawy produktów rolnych i hodowli zwierząt gospodarskich aż po przetwórstwo przemysłowe produktów rolnych i zwierząt. Sektor ten obejmuje zarówno spółdzielnie producentów rolnych, jak i konsorcja spółdzielni (lub podobne porozumienia), które przetwarzają i wprowadzają do obrotu produkty rolne dla swoich członków. Spółdzielnie rolnicze istnieją prawie w każdym kraju na świecie. Są one bardzo dobrze reprezentowane zarówno w gospodarkach rozwiniętych, jak i wschodzących oraz przyczyniają się do bezpieczeństwa żywnościowego i ograniczania ubóstwa w różnych częściach świata. Pomagają rolnikom zwiększyć zyski i dochody poprzez łączenie zasobów w celu wspierania wspólnych projektów i wzmocnienia pozycji gospodarczej.

Charakteryzując spółdzielczą branżę rolniczą zebrano dane z 668 organizacji z 35 krajów (439 z Europy, 189 z obu Ameryk, 38 z Azji, 2 z Afryki. Aż 454 przedsiębiorstwa miały obrót ponad 100 mln USD ${ }^{15}$. Największe spółdzielnie w sektorze rolnictwa i przemysłu spożywczego według obrotu prezentuje tabela 4.2 .

W dwudziestce spółdzielni z najwyższymi obrotami z branży rolniczej znalazło się 11 spółdzielni z Europy - 3 z Dani, 1 z Irlandii, 2 z Francji, 1 z Holandii, 3 z Niemiec i 1 ze Szwajcarii. Listę otwiera japońska Zen-noh z obrotem prawie 39 mld dolarów amerykańskich. Największą reprezentację mają spółdzielnie z USA - 4 na 20 wskazanych spółdzielni z najwyższymi obrotami. O powszechności spółdzielczego sposobu gospodarowania świadczy obecność w rankingu spółdzielni z innych kontynentów. W okresie 2011-2015 największym przyrostem obrotów charakteryzowały się:

\footnotetext{
${ }^{14}$ World Co-operative Monitor...

${ }^{15}$ Tamże.
} 
brazylijska Copersucar (134\%), niemiecka Bay Wa (56\%), duńska Arla Foods Amba (40\%) i duńska DLG (33,5\%).

Tabela 4.2. Największe spółdzielnie w sektorze rolnictwa i przemysłu spożywczego według GLOBAL 300 Report 2017

\begin{tabular}{|c|c|c|c|}
\hline Pozycja & Przedsiębiorstwo & Kraj & Obrót w mld USD \\
\hline 1 & Zen-noh & Japonia & 38,80 \\
\hline 2 & CHS Inc. & USA & 34,58 \\
\hline 3 & NH Nonghyup* & Republika Korei & 33,94 \\
\hline 4 & Bay Wa & Niemcy & 16,46 \\
\hline 5 & Dairy Farmers of America & USA & 13,80 \\
\hline 6 & Fonterra Co-operative Group & Nowa Zelandia & 13,02 \\
\hline 7 & Land O'Lakes, Inc. & USA & 13,01 \\
\hline 8 & Hokuren & Japonia & 12,53 \\
\hline 9 & FrieslandCampina & Holandia & 12,42 \\
\hline 10 & Arla Foods Amba & Dania & 11,35 \\
\hline 11 & Danish Crown & Dania & 8,80 \\
\hline 12 & Growmark, Inc. & USA & 8,73 \\
\hline 13 & DLG & Dania & 8,05 \\
\hline 14 & Agravis & Niemcy & 7,65 \\
\hline 15 & Copersucar SA & Brazylia & 7,61 \\
\hline 16 & Südzucker & Niemcy & 7,47 \\
\hline 17 & Kerry Group & Irlandia & 6,73 \\
\hline 18 & Fenaco & Szwajcaria & 6,27 \\
\hline 19 & InVivo & Francja & 6,23 \\
\hline 20 & Terrena & Francja & 5,55 \\
\hline
\end{tabular}

* NH Nonghyup łącznie z danymi z bankowych i ubezpieczeniowych spółek zależnych grupy

Źródło: World Co-operative Monitor, Exploring the Co-operative Economy Report 2017, s. 16, www. euricse.eu/wp-content/uploads/2017/11/WCM_2017-web-EN.pdf [data dostępu: 30.06.2019]. 
Ranking Global 300 z roku 2017 prezentuje największe spółdzielnie z obrotem wyrażonym w dolarach międzynarodowych (zgodnie z definicją Banku Światowego dolar międzynarodowy to równowartość ilości towarów i usług w danym kraju porównywalna z tą, którą można kupić za dolara amerykańskiego w Stanach Zjednoczonych). We wspomnianym rankingu znalazły się dwie polskie spółdzielnie: Spółdzielnia Mleczarska „Mlekovita” - na 231 pozycji rankingu, z obrotem 1,96 mld USD, oraz Spółdzielnia Mleczarska „Mlekpol” - na pozycji 247, z obrotem 1,73 mld $\mathrm{USD}^{16}$.

Mimo imponujących, według Raportu Global 300, danych przedsiębiorstw spółdzielczych z sektora rolnictwa i przemysłu spożywczego, sami spółdzielcy w Unii Europejskiej zauważają, że rola spółdzielni rolniczych nie zawsze jest w pełni doceniana podczas debat na temat przyszłości i zrównoważenia unijnego łańcucha rolno-spożywczego. Wskazuje na to Copa Cogeca - europejska organizacja zrzeszająca rolnicze związki zawodowe i organizacje spółdzielcze. Organizacja promuje spółdzielnie rolno-spożywcze i leśne jako kluczowe narzędzie kształtujące rolnictwo w przyszłości, wykorzystujące kreatywność i odporność obszarów wiejskich $^{17}$.

Działając w formie spółdzielni, pojedyncze gospodarstwa mając większą ofertę podażową i z drugiej strony, dokonując większych zamówień, przez to zwiększają swoją siłę przetargową w negocjacjach z odbiorcami i dostawcami, którymi na globalnym rynku są korporacje międzynarodowe. Dzięki temu poszczególni rolnicy, członkowie spółdzielni mają wpływ na swoje miejsce w łańcuchu dostaw „od pola do stołu”. Są to sprawdzone działania rolników europejskich. O znaczeniu spółdzielni dla rynku rolnego świadczy fakt, że dziewięciu spośród dziesięciu francuskich

\footnotetext{
${ }^{16}$ World Co-operative Monitor..., s. 86.

${ }^{17}$ Europejskie spółdzielnie rolnicze i leśne realizuja wszystkie cele zrównoważonego rozwoju, https://copa-cogeca.eu/Main.aspx?page $=$ HomePage\&lang $=$ pl [data dostępu: 30.06.2019].
} 
rolników to członkowie spółdzielni, w Holandii jest to aż 98\%, a w Danii w spółdzielniach jest zrzeszonych 100\% rolników ${ }^{18}$.

\subsection{Spółdzielczość w Polsce}

O ile przed odzyskaniem niepodległości w 1918 roku powszechnie tworzono spółdzielnie w obronie polskiej własności ziemi i kapitału, to w okresie komunizmu i następnie transformacji ustrojowej obserwujemy kurczenie się sektora spółdzielczego.

Przygotowana przez Krajową Radę Spółdzielczą przed VI Kongresem Spółdzielczości (najwyższym organem samorządu spółdzielczego) w Polsce w grudniu 2016 roku statystyka spółdzielni czynnych w działalności w tym roku zawiera 15 branż. W tabeli 4.3. podano liczbę spółdzielni w poszczególnych branżach i rok założenia najstarszej w danej branży spółdzielni. Podana liczba spółdzielni czynna w działalności w 2016 roku różni się od statystyk GUS, według których w tym roku istniało (składało sprawozdanie) 17633 spółdzielni. Ich liczba w latach 2007-2011 zmniejszyła się z 18128 do 17 155. Od roku 2012 zaznaczył się wzrost liczby funkcjonujących przedsiębiorstw spółdzielczych. W kolejnych latach liczba spółdzielni nowo zarejestrowanych była wyższa od wyrejestrowanych. W roku 2017 zarejestrowano w rejestrze REGON 338 nowych spółdzielni, wyrejestrowano 286. Jednakże według danych GUS za rok 2018 liczba spółdzielni wynosiła już tylko 11 655, nastąpił drastyczny spadek (o 34,1\%) w stosunku do roku poprzedniego (w 2017 roku było 17694 spółdzielni) ${ }^{19}$.

${ }^{18}$ Ruch spółdzielczy w Europie i instrumenty wsparcia, https://www.senat.gov.pl/ gfx/senat/pl/senatopracowania/141/plik/ot-644.pdf [data dostępu: 30.06.2019].

${ }^{19}$ Zmiany strukturalne podmiotów gospodarki narodowej $w$ rejestrze REGON 2018 rok, GUS, Warszawa 2019, s. 82, https://stat.gov.pl/obszary-tematyczne/ podmioty-gospodarcze-wyniki-finansowe/zmiany-strukturalne-grup-podmiotow/ zmiany-strukturalne-grup-podmiotow-gospodarki-narodowej-w-rejestrze-regon2018-rok,1,23.html [data dostępu: 15.12.2019]. 
Tabela 4.3. Spółdzielnie i branże spółdzielcze w Polsce

\begin{tabular}{clcc}
\hline Lp. & \multicolumn{1}{c}{ Branża spółdzielcza } & $\begin{array}{c}\text { Liczba } \\
\text { spółdzielni } \\
\text { czynna } \\
\text { w działalności }\end{array}$ & $\begin{array}{c}\text { Rok } \\
\text { założenia } \\
\text { najstarszej } \\
\text { spółdzielni }\end{array}$ \\
\hline \hline 1 & Gminne Spółdzielnie „Samopomoc Chłopska” & 1115 & 1951 \\
\hline 2 & Spółdzielnie Mleczarskie & 137 & 1896 \\
\hline 3 & Spółdzielnie Ogrodniczo-Pszczelarskie & 52 & 1884 \\
\hline 4 & Rolnicze Spółdzielnie Produkcyjne & 682 & 1948 \\
\hline 5 & Kółka Rolnicze & 489 & 1862 \\
\hline 6 & Banki Spółdzielcze & 563 & 1861 \\
\hline 7 & PSS „Społem” & 310 & 1868 \\
\hline 8 & Spółdzielnie Mieszkaniowe & 3722 & 1890 \\
\hline 9 & $\begin{array}{l}\text { Spółdzielnie Pracy i Usług, Spółdzielnie } \\
\text { Budowlane }\end{array}$ & 576 & 1872 \\
\hline 10 & Spółdzielnie Inwalidów i Niewidomych & 167 & 1944 \\
\hline 11 & $\begin{array}{l}\text { Spółdzielnie Rękodzieła Ludowego } \\
\text { i Artystycznego „Cepelia” }\end{array}$ & 6532 & 1926 \\
\hline 12 & Spółdzielnie Rzemieślnicze & 1054 & 1933 \\
\hline 13 & Spółdzielcze Kasy Oszczędnościowo-Kredytowe & 55 & 1861 \\
\hline 14 & Spółdzielnie Socjalne & 468 & 2000 \\
\hline 15 & Spółdzielcze Grupy Producentów Rolnych & 9532 & $\times$ \\
\hline & Razem & & \\
\hline
\end{tabular}

Źródło: opracowanie własne na podstawie www.krs.org [data dostępu: 15.12.2019].

Przedsiębiorstwa spółdzielcze swoją historią sięgają drugiej połowy XIX wieku. Jedynie cztery spośród piętnastu wyróżnionych branż spółdzielczych mają krótszą historię. Rolnicze Spółdzielnie Produkcyjne powstawały w procesie „rozkułaczania” wsi polskiej i kolektywizacji 
realizowanej przez komunistów w latach 50. XX wieku. W ich przypadku inaczej niż przy tworzeniu przedwojennych kółek rolniczych, czy spółdzielni w ogóle - gdzie łączy się zasoby będące prywatną własnością członków - prywatną własność innych osób przejęły, niejednokrotnie pod przymusem władzy ludowej, osoby tworzące rolniczą spółdzielnię produkcyjną. Podobnie Gminne Spółdzielnie „Samopomoc Chłopska” przejęły po II wojnie światowej w ramach „kolektywizacji” działające na wsiach spółdzielnie rolnicze i drobne zakłady wytwórcze. I to właśnie te złe doświadczenia stały się barierą w tworzeniu spółdzielni przez rolników po 1989 roku w Polsce. Komunistyczne wypaczenie idei spółdzielczości i właściwie nacjonalizacja przedsiębiorstw spółdzielczych do dziś powodują negatywne skojarzenia wobec spółdzielni.

Chociaż mające najkrótszą historię Spółdzielnie Socjalne i Spółdzielcze Grupy Producentów Rolnych być może pozwolą na odwrócenie niekorzystnych trendów rozwoju przedsiębiorstw spółdzielczych w Polsce. Mamy jednak w drugiej gospodarce rynkowej fenomen trzech branż spółdzielczych. Są to banki spółdzielcze, spółdzielnie mleczarskie i spółdzielnie spożywców. Blisko 600 banków spółdzielczych to możliwość gromadzenia rodzimego kapitału finansowego w skali lokalnej. Dla spółdzielców, będących najczęściej członkami spółdzielni mleczarskich, to też pewna dostępność kredytu. Powszechne Spółdzielnie Spożywców, którym nazwę „Społem” wymyślił Stefan Żeromski, prowadząc własne sklepy, piekarnie, zakłady produkcyjne i gastronomiczne, okazały się konkurencyjne wobec zachodnich sieci handlowych. W swojej działalności spółdzielnie powyższych branż są ze sobą powiązane wzajemnymi transakcjami handlowymi, ale też wspólnymi działaniami w sferze społeczno-samorządowej.

Warto też wskazać przykłady niewielkich spółdzielni działających z sukcesem w skali międzynarodowej takich jak Spółdzielnia „Pieczarka Siedlecka”. Powstała na początku 2007 roku, jest grupą producentów specjalizujących się w produkcji wysokojakościowych grzybów: pieczarki białej i pieczarki brązowej, zwanej królewską. Zajmuje się również skupem i sprzedażą grzybów. Sprzedaje na rynku krajowym do sieci marketów, 
przetwórni, firm z branży gastronomicznej. Jednak zdecydowana większość produkcji jest przedmiotem eksportu do wielu krajów Europy ${ }^{20}$.

Kooperacja pozwala rolnikom polepszyć ich pozycję w łańcuchu żywnościowym. Wydaje się, że rozumieją to też sami rolnicy i ich organizacje w Polsce, czemu dali wyraz organizując konferencję w czerwcu 2019 pod tytułem „Rola spółdzielni we wzmacnianiu pozycji gospodarczej i społecznej rolników”. Podczas niej Federacja Branżowych Związków Producentów Rolnych i przedstawiciele Europejskiej Rady Młodych Rolników CEJA przekonywali, że „kooperatywy są trendy”21.

Nie bez znaczenia pozostaje tu polityka europejska sprzyjająca spółdzielczości poprzez wprowadzanie nowych instrumentów prawnych ułatwiających zakładanie i funkcjonowanie spółdzielni ${ }^{22}$. Dlatego tak ważne są też zmiany przepisów prawnych w Polsce odnośnie do spółdzielni rolników ${ }^{23}$, choć ciągle krytykowane za brak rozwiązań kompleksowych.

Zdaniem autorki, to właśnie młodzi rolnicy, dla których spółdzielnia nie budzi pejoratywnych skojarzeń właściwie rozumieją przewagę spółdzielczej organizacji działalności gospodarczej. Główną motywacją pozostaje zawsze możliwość odniesienia korzyści ekonomicznych i pozaekonomicznych. I to kryterium powinny uwzględniać stosowane instrumenty prawne.

\section{Podsumowanie}

Przeprowadzona analiza kondycji przedsiębiorstw spółdzielczych na podstawie raportów organizacji spółdzielczych pokazuje, że spółdzielnie

${ }^{20}$ Pieczarka Siedlecka, http://www.pieczarkasiedlecka.pl [data dostępu: 20.06.2019].

${ }^{21}$ https://www.gov.pl/web/rolnictwo/spoldzielczosc-jako-przyszlosc-rolnictwa [data dostępu: 30.06.2019].

22 A. Suchoń, Prawne determinanty rozwoju spótdzielni rolniczych $w$ krajach Unii Europejskiej. Aspekty europejskie, krajowe i regionalne, „Studia Iuridica Lublinensia” 2017, t. XXVI, nr 1.

${ }^{23}$ Ustawa z dnia 4 października 2018 r. o spółdzielniach rolników, Dz.U. z 2018 r., poz. 2073. 
jako odnoszące sukcesy przedsiębiorstwa jednoczące ludzi wokół wspólnych celów gospodarczych, społecznych i środowiskowych działają na całym świecie. To wspólne działanie widać szczególnie na wsi i terenach wiejskich.

Na świecie dynamika rozwoju spółdzielni z tego sektora (mierzona przyrostem obrotu) w latach 2011-2015 wynosiła prawie 18\%. Takim samym wzrostem wykazały się największe na świecie spółdzielnie z branży finansowej i bankowej. W Polsce niestety branża spółdzielcza drastycznie się kurczy. Transformacja ustrojowa zachowała regulacje prawne z poprzedniego ustroju i to pozostaje główną przyczyną tego stanu. Szans upatrywać można jednak w spółdzielniach tworzonych przez młodych rolników zgodnie z nowymi przepisami. Nie bez znaczenia pozostaje także propagowanie idei spółdzielczości i spółdzielczego modelu biznesowego wśród młodzieży i studentów. 